\title{
Influence of Pythium oligandrum on Mycelia and Production of Zoo-and Oo-spores of Two Phytopathogenic Pythium spp.
}

\author{
Shaima Mohamed Nabil Moustafa ${ }^{1,2}$ \\ ${ }^{1}$ Biology Department, College of Science, Jouf University, P.O. Box: 2014, Sakaka, Saudi Arabia. \\ ${ }^{2}$ Department of Botany and Microbiology, Faculty of Science, Minia University, Minia City- 61519, Egypt.
}

\begin{abstract}
Pythium oligandrum is one of the best known fungi in biological control of many fungal plant diseases. The objective of this study was conducted to highlight the possibility of using cultural filtrate of this fungus in inhibiting the growth of reproducting units of the pathogenic Pythium aphanidermatum and $P$. diclinum. Two isolates of each fungus were studied. Ability of $P$. oligandrum to grow and develop on V-8 liquid medium was tested in order to study its effect on mycelium growth, zoospore and oospore production of each of the pathogenic pythia of $P$. aphanidermatum and $P$. diclinum. Cultural filtrate of $P$. oligandrum (quarter and half concentration) significantly inhibited mycelial growth and the production of zoospores and oospores of the pathogenic tested fungi. The rate of inhibition in all treatments reached more than $90 \%$ in case of the use of half concentration of the cultural filtrate of $P$. oligandrum. The study will provide information for the use of cultural filtrate of potential selected isolates of $P$. oligandrum in biological control of some fungal diseases especially in aquaculture. The outcomes of this research can be easily applied in aquatic farming but need further work on different types of pathogenic fungi.
\end{abstract}

Keywords: Cultural filtrate of $P$. oligandrum, Oospores, Pythium aphanidermatum, Pythium diclinum, zoospores.

*Correspondence: shymaa.nabil@ju.edu.sa; +966537283495

(Received: 01 February 2019; accepted: 27 February 2019)

Citation: Shaima Mohamed Nabil Moustafa, Influence of Pythium oligandrum on Mycelia and Production of Zoo-and Oo-spores of Two Phytopathogenic Pythium spp., J Pure Appl Microbiol., 2019; 13(1):233-240 doi: 10.22207/JPAM.13.1.24

C The Author(s) 2019. Open Access. This article is distributed under the terms of the Creative Commons Attribution 4.0 International License which permits unrestricted use, sharing, distribution, and reproduction in any medium, provided you give appropriate credit to the original author(s) and the source, provide a link to the Creative Commons license, and indicate if changes were made. 


\section{INTRODUCTION}

As a result of the steady increase in human numbers, those interested in agriculture are looking for ways to increase agricultural crops despite the many challenges. Crop diseases have recently spread in a high way. This has led to strenuous attempts to increase the productivity of agricultural crops. which provided methods of chemical control of plant diseases. This calls for research on safe ways to control fungal plant diseases, including biological control. Among fungi that causes serious diseases for a large number of agricultural crops are Pythium spp.

Pythiaceous (Pythium spp. $=$ pythia) fungi belong to Kingdom Myceteae. This kingdom is one of realms of living organisms. The majority of members of these fungi are microscopic organisms living either in a saprophytic or parasitic manner. Pathogenic pythia cause diseases of plants, animals and humans ${ }^{1}$. Pathogenic fungi of the genus Pythium used in this study caused serious plant diseases resulting in a significant loss in the yield of those plants ${ }^{2}$. On the other hand, Pythium oligandrum Dreschler, used in this research, well known for its role in the biological control to many fungal diseases of crop plants s.4. $^{3,4}$.

Although $P$. oligandrum belongs to the same genus of pathogenic pythia, it is useful not only for its role in biological control of many phytopathogenic Puthium spp. but also for its secretion of oxin-like substances that increase plant growth and yield ${ }^{5}$.

Apparently, farmers are used to use fungicides for disease control. These chemicals are a double-edged sword, many of which can control the disease, but at the same time they destroy other useful fungi in the soil. They also cause long-term resistance to fungi which become not affected by pesticides ${ }^{6}$.

From the same field, two pathogenic pythia of $P$. aphanidermatum (Edson) Fitzp. and $P$. diclinum Tokunaga were isolated and identified morphologically followed by confirmation of identification using molecular criteria ${ }^{7}$. Additionally, many isolates of $P$. oligandrum were also isolated and a previous study was conducted to select strongest isolates used in the biological control of some fungal plant diseases and also positive in the secretion of substances similar to auxins that induced to increase growth of plants ${ }^{4,5}$.
Metalaxyl are most commonly used for chemical control of plant diseases caused by Pythium ${ }^{8,9}$. Many previous studies have shown that this fungicide is harmful to pathogenic and beneficial fungi. Therefore, the concern of many plant pathologists is to look for useful natural materials that do not cause pollution to the environment.

One of the methods that explains the biological control of a fungus is the secretion of substances that inhibits growth of other microorganisms and sometimes kills them ${ }^{10}$. This is the case with the $P$. oligandrum, in addition to the secretion of substances that stimulate growth of the plant. Therefore, it has been benefited from this situation in the cultivation of $P$. oligandrum in an appropriate liquid cultural medium for the purpose of obtaining a filtrate containing those useful substances for biological control of some phytopathogenic $P$. aphanidermatum and $P$. diclinum. Nutrient residues which were remained in the cultural medium after growth of $P$. oligandrum act as sources of nutrients for plant growth and act as fertilizers.

Mycelial growth, production of zoospores and oospores will be studied as markers to confirm efficacy of the cultural filtrate of $P$. oligandrum. Asexual reproduction occurs in $P$. aphanidermatum and $P$. diclinum through zoospores produced in the water medium. Both fungi produce large amounts of zoospores, which are considered to be unit of infection to a new host plant ${ }^{1}$. For this reason, inhibiting production or killing of these zoospores is a means of reducing the multiplication of these pathogenic fungi. Fungal mycelia are considered as a means of asexual reproduction. Sometimes, injury and infection may be caused by these threads by moving to the surface of the plant. These two pathogenic pythia produce sexual oospores in all conditions, both favorable and unfavorable during their life cycle. Oospores are resistant to inappropriate factors and can survive for a long time in the soil, host cells or plant residues to grow after conditions have improved, producing numerous zoospores ${ }^{1}$. In this work, study the effect of cultural filtrate of $P$. oligandrum on mycelium growth, zoospore production and oospore formation of two pathogenic fungi of $P$. aphanidermatum and $P$. diclinum is a topic worth investigation. 
Subsequently, the aim of this study is to test the efficiency of cultural filtrate of $P$. oligandrum, which was known for its ability to control some pathogenic fungi of some crop plants, in the control of $P$. aphanidermatum and $P$. diclinum that cause many plant diseases.

\section{MATERIAL AND METHODS \\ Fungi and isolates}

Two isolates of $P$. oligandrum which previously gave strongest action against some pathogenic pythia were selected to perform these experiments. Isolates of JU0328 and JU0329 were selected on the basis of their effectiveness as biocontrol agents. They were obtained, earlier, during an investigation by the author ${ }^{4}$. Two pathogenic pythia of each of Pythium aphanidermatum (isolates JU0010 and JU0011), and Pythium diclinum (JU0020 and JU0021) were kindly obtained from Dr. Hani M. A. Abdelzaher, Professor of Mycology, Biology Department, College of Science, Jouf University, Saudi Arabia”. Stock cultures were stored on corn meal agar (CMA: Difco).

\section{Pathogenicity test}

$P$. aphanidermatum and $P$. diclinum used in this experiment were isolated in $2012^{7}$. It is important to test its ability to infect a crop plant and to prove Koch's postulates ${ }^{11}$, because succession of fungal cultivation over a long period of time may cause loss of its ability to infect and cause diseases. Inocula were prepared by mixing $5 \mathrm{gm}$ of small pieces of corn leaves $(\mathrm{cm} \times \mathrm{cm})$, two grams of glucose and $10 \mathrm{ml}$ of distilled water, all in a $250 \mathrm{ml}$ Earlenmayer flask followed by autoclave sterilization. After cooling the bottles and reached to room temperature, each flask containing the above cited mixture was added with 3 colonized V-8 agar disks by each fungus and incubated at $25^{\circ} \mathrm{C}$ for 10 days. Two and a half per cent of inoculum concentration was arranged by collaborating $1 \mathrm{gm}$ of the inoculum in the Erlenmeyer flask with $50 \mathrm{~g}$ of dried clay sandy soil using a disinfected mortar and pestle. Two and a half $\mathrm{gm}$ of this combination were then added to $97.5 \mathrm{gm}$ of sterilized clay loam soil and mixed thoroughly. Seeds of cucumber (Cucumis satives L.) were rinsed in $\mathrm{NAOCl} 2 \%$ for $3 \mathrm{~min}$ and then washed thoroughly by sterilized $\mathrm{H}_{2} \mathrm{O}$ followed by $1 \mathrm{~min}$ in $70 \%$ ethanol and finally three times using sterilized deionized water. Pre-emergence pathogenicity test was performed using viable seeds which confirmed by pre-germination test (to select the viable ones). Twenty cucumber seeds were imbedded in each pot for pathogenicity test. This experiment was done in a growth chamber at $25^{\circ} \mathrm{C}$ with illumination of $12 \mathrm{~h}$ photoperiod $\left(91 \mu \mathrm{mol} \mathrm{m}^{-2} \mathrm{~S}^{-1}\right)$. Percentage of Damping-off was analyzed by using differences between emergence of cucumber seeds of the infested against the control pots.

Preparation of cultural filtrate of $P$. oligandrum

The two studied isolates of $P$. oligandrum were cultured on V-8 (Medium was prepared with $200 \mathrm{ml}$ of V-8 juice, $2 \mathrm{gm} \mathrm{CaCO}_{3}, 25 \mathrm{gm}$ agar and the final solution was completed to 1 liter using distilled water with $\mathrm{pH}$ 5.7. The acidic $\mathrm{pH}$ of the medium helps fungal growth and suppresses bacterial growth) juice medium at $28 \mathrm{C}$ for 8 days under stagnant situation. Accordingly, aliquots of $100 \mathrm{ml}$ of the medium were placed in 500 $\mathrm{ml}$ Erlenmeyer flasks. After sterilization, two discs of V-8 agar medium, containing growth of $P$. oligandrum, were placed in each flask, under aseptic conditions in the isolation cabinet and followed by incubation in circumstances as mentioned above. After the incubation period, the filtrate was collected by successive filtration through a gauze cloth followed by cellulosic filter paper. This filtrate was used directly, or kept in a deep freezer at a $-20^{\circ} \mathrm{C}$. An initial experiment was carried out to ensure that the filtrate was not affected by long low temperature preservation. It is worth noting that, frequent freezing and thawing processes adversely affect the effectiveness of the filtrate.

Effect of cultural filtrate of $P$. oligandrum on Mycelial growth of $P$. aphanidermatum and $P$. diclinum on V-8 agar medium

Aliquots of $3.75 \mathrm{ml}$ of cultural filtrate of each of the two isolates of $P$. oligandrum was mixed with $11.25 \mathrm{ml}$ sterilized melted $\left(60^{\circ} \mathrm{C} \pm 3\right)$ V-8 agar medium into a 9-cm sterile Petri dish, under aseptic condition (quarter concentration). Half concentration was prepared by mixing 7.5 $\mathrm{ml}$ of cultural filtrate of each of the two isolates of $P$. oligandrum mixed with $7.5 \mathrm{ml}$ sterilized melted $\left(60^{\circ} \mathrm{C} \pm 3\right) \mathrm{V}-8$ agar medium into a $9-\mathrm{cm}$ sterile Petri dish, under aseptic condition. After solidification of the mixed medium, $0.5 \mathrm{~cm}$ 
diameter V-8 agar disc, taken from the margins of the active growth of $P$. aphanidermatum or $P$. diclinum colony, was located in the middle of each Petri dish. Incubation was performed at $25^{\circ} \mathrm{C}$ in the dark. Mycelial growth was calculated by measuring colony diameters every day at two points on each plate and taking the average value. Three replicates were used in this experiment; although the probability of variability of results in such measurements was low. The experiment was repeated twice to confirm reusability and stability of results.

Dry weight of mycelial biomass growth of $\boldsymbol{P}$. aphanidermatum and $P$. diclinum on V-8 liquid medium

This was performed at the same concentrations as previously mentioned, but in the case of liquid medium.

Effect of cultural filtrate of $P$. oligandrum on zoospore production of $P$. aphanidermatum and P. diclinum

Pieces $(1 \times 0.5 \mathrm{~cm})$ of maize leaf parallel venation blades were putted adjacent the edges of the fungal colony of each of $P$. aphanidermatum or $P$. diclinum and incubated at $25^{\circ} \mathrm{C}$ for $24 \mathrm{~h}$. During this period, fungal mycelia intersect the tissue of the maize leaf sections and spread through it. Colonized maize leaf blades sections were then transferred to Petri dishes containing $12 \mathrm{ml}$ of the following solution mixtures: 1- Filtrate (as it is without any additions) of $P$. oligandrum; half dilution $(6 \mathrm{ml}$ of filtrate of $P$. oligandrum $+6 \mathrm{ml}$ sterilized distilled water); or quarter dilution ( $4 \mathrm{ml}$ of filtrate of $P$. oligandrum $+8 \mathrm{ml}$ sterilized distilled water) to determine the effect of cultural filtrate of $P$. oligandrum on zoospore production of $P$. aphanidermatum and $P$. diclinum at $20^{\circ} \mathrm{C}$. Control trial was done using sterilized distilled water.

Zoospores gathering in P. aphanidermatum and $P$. diclinum are produced within lobulated and filamentous shape zoosporangia, respectively. When these spores mature in zoosporangia, it exits out into bubble soap-like vesicles, followed by a process of formation and full maturity. After differentiation of zoospores within the vesicles, which takes a period of time, the vesicle bursts producing plenty biflagellated kidney shaped zoospores.

Three dishes per each strength were performed per isolate. The experiment was repeated twice.

Effect of cultural filtrate of $P$. oligandrum on oospore production of $P$. aphanidermatum and $P$. diclinum

$P$. aphanidermatum and $P$. diclinum were grown to yield oospores at $28^{\circ} \mathrm{C}$ for 15 days in $100 \mathrm{ml}$ Erlenmeyer flasks containing $10 \mathrm{ml}$ of $\mathrm{V}-8$ juice (Which has been planted with $P$. oligandrum for eight days at $28^{\circ} \mathrm{C}$ ). Precautions must be taken to prevent contamination of the filtrate by using stilarized conical flasks, glass funnels, gauze cloth and Seitz filter, inside an isolation cabinet. Oospores were then gained by shredding fungal mats in a homogenizer at high speed for $3 \mathrm{~min}$. The subsequent suspension was filtered through a sieve, the size of which was chosen in relation to the oospore dimension in order to collect the most. Number of mature oospores was counted per $\mathrm{ml}$ solution.

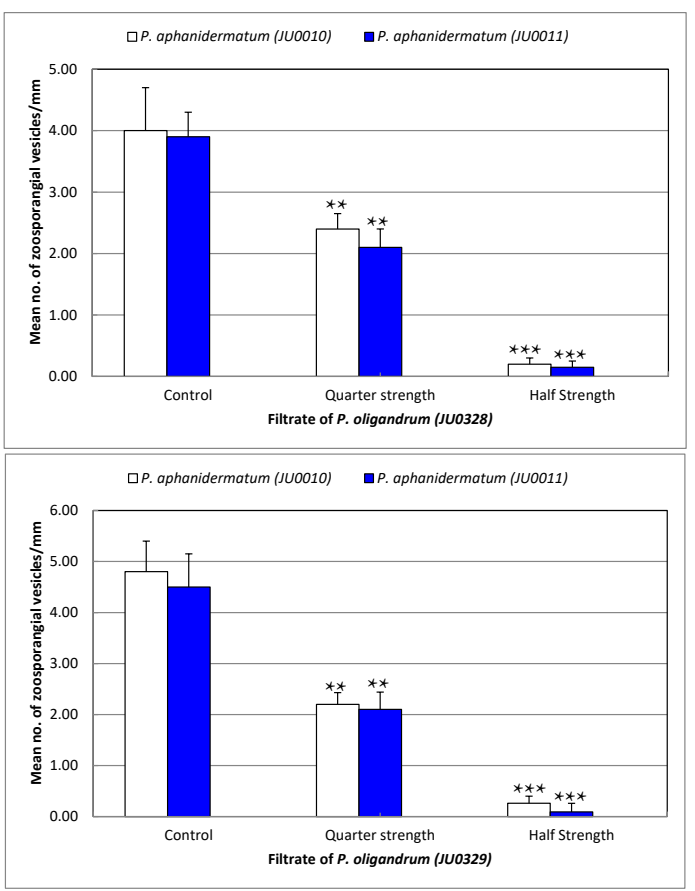

Fig. 1. Effect of cultural filtrate of two isolates of $P$. oligandrum on zoospore production by two isolates of $P$. aphanidermatum after $24 \mathrm{~h}$ at $20^{\circ} \mathrm{C}$ in the dark. Bars above all drawing column, represent the standard error of the average data from three replicates and reflect differences between averages of the samples compared to the control sample. Significant values against control represent: ${ }^{* *}=$ highly significant at $p<0.01, * * *=$ very significant at $p<0.001$. 
Table 1. Effect of the inhibitory activity of different strength of cultural filtrate of two isolates of Pythium oligandrum on mycelial radial growth of two isolates of each of Pythium aphanidermatum and Pythium diclinum grown on solid V-8 agar medium at $25^{\circ} \mathrm{C}$ in the dark

\begin{tabular}{|c|c|c|c|c|c|c|c|c|}
\hline \multirow[b]{2}{*}{ Treatment } & \multicolumn{2}{|c|}{$\begin{array}{l}\text { P. aphanidermatum } \\
\text { (JU0010) }\end{array}$} & \multicolumn{2}{|c|}{$\begin{array}{l}\text { P. aphanidermatum } \\
\text { (Jบ0011) }\end{array}$} & \multicolumn{2}{|c|}{$\begin{array}{l}\text { P. diclinum } \\
\text { (JU0020) }\end{array}$} & \multicolumn{2}{|c|}{$\begin{array}{l}\text { P. diclinum } \\
\text { (JU0021) }\end{array}$} \\
\hline & $\begin{array}{c}\text { Radial } \\
\text { growth } \\
\text { rate } \\
(\mathrm{mm} / 24 \mathrm{~h})^{4}\end{array}$ & $\begin{array}{c}\% \\
\text { inhibition }\end{array}$ & $\begin{array}{l}\text { Radial } \\
\text { growth } \\
\text { rate } \\
(\mathrm{mm} / 24 \mathrm{~h})\end{array}$ & $\begin{array}{c}\% \\
\text { inhibition }\end{array}$ & $\begin{array}{c}\text { Radial } \\
\text { growth } \\
\text { rate } \\
(\mathrm{mm} / 24 \mathrm{~h})\end{array}$ & $\begin{array}{c}\% \\
\text { inhibition }\end{array}$ & $\begin{array}{l}\text { Radial } \\
\text { growth } \\
\text { rate } \\
(\mathrm{mm} / 24 \mathrm{~h})\end{array}$ & $\begin{array}{c}\% \\
\text { inhibition }\end{array}$ \\
\hline \multicolumn{9}{|c|}{ P. oligandrum JU0328 } \\
\hline Control (Full strength) ${ }^{1}$ & $35 \pm 1$ & - & $31 \pm 1$ & - & $44 \pm 3$ & - & $43 \pm 2$ & - \\
\hline Quarter strength ${ }^{2}$ & $26 \pm 1$ & $25.7^{* *}$ & $22 \pm 3$ & $29.0^{* *}$ & $34 \pm 2$ & $22.7^{* *}$ & $35 \pm 2$ & $18.6^{*}$ \\
\hline Half strength ${ }^{3}$ & $21 \pm 1$ & $40.1^{* *}$ & $19 \pm 2$ & $38.7^{* *}$ & $29 \pm 2$ & $34.1^{* *}$ & $30 \pm 1$ & $30.2^{* *}$ \\
\hline \multicolumn{9}{|c|}{ P. oligandrum JU0329 } \\
\hline Control (Full strength) & $33 \pm 1$ & - & $29 \pm 1$ & - & $39 \pm 3$ & - & $40 \pm 2$ & - \\
\hline Quarter strength & $26 \pm 1$ & $21.2^{* *}$ & $22 \pm 3$ & $24.1^{* *}$ & $32 \pm 2$ & $17.9^{*}$ & $34 \pm 2$ & $15.0^{*}$ \\
\hline Half strength & $20 \pm 1$ & $39.4^{* *}$ & $17 \pm 2$ & $41.4^{* *}$ & $26 \pm 2$ & $33.3^{* *}$ & $28 \pm 1$ & $30.0^{* *}$ \\
\hline
\end{tabular}

${ }^{1}$ Control = Full strength $-12 \mathrm{ml} \mathrm{V-8}$ agar medium; ${ }^{2}$ Quarter strength $=3 \mathrm{ml}$ filtrate $+9 \mathrm{ml} \mathrm{V}-8$ agar medium;

${ }^{3} \mathrm{Half}$ strength $=6 \mathrm{ml}$ filtrate $+6 \mathrm{ml} \mathrm{V-8}$ agar medium; ${ }^{4}$ Radial mycelia growth was determined by measuring colony diameters after $24 \mathrm{~h}$ at two points on each plate until growth reached. The dish wall side and taking the average. Data are the mean of six reads + standard error. ${ }^{*}{ }^{* *}$ Data are the mean of three replicates and reflect differences between averages of the samples compared to the control sample. Significant values against control represent: ${ }^{*}=$ moderately significant, ${ }^{* *}=$ highly significant at $p<0.01$

\section{Statistical analysis}

ANOVA was assessed by Minitab statistical software (Ver. 12).

\section{RESULTS \\ Pathogenicity test}

Results showed that $P$. aphanidermatum (JU0010 \& JU0011) and P. diclinum (JU0020 \& JU0021) gave a high pathogenicity (100\%) rate while ensured the inability of $P$. oligandrum to cause any damping-off (Fig. 1).

Effect of cultural filtrate of $P$. oligandrum on radial mycelial growth of $P$. aphanidermatum and $P$. diclinum on V-8 agar medium

Table 1 appeared that filtrate of $P$. oligandrum (JU0238) reduced radial mycelial growth by $26 \%$ in the case of $P$. aphanidermatum (JU0010) and $29 \%$ in the second isolate of JU0011 when using the quarter strength of filtrate concentration. Half strength of filtrate concentration of $P$. oligandrum (JU0238) reduced radial mycelial growth by $40.1 \%$ in the case of $P$. aphanidermatum (JU0010) and $38.7 \%$ in the second isolate of JU0011. It also appeared that filtrate of $P$. oligandrum (JU0238) reduced radial mycelial growth by $22.7 \%$ in the case of P. diclinum (JU0020) and $18.6 \%$ in the second isolate of JU0021 when using the quarter strength of filtrate concentration. Half strength of filtrate concentration of $P$. oligandrum (JU0238) reduced radial mycelial growth more significant that in quarter concentration.

Effect of cultural filtrate of $P$. oligandrum on mycelial dry weight of $P$. aphanidermatum and $P$. diclinum on V-8 liquid medium

The effect of cultural filtrate of $P$. oligandrum on mycelial biomass growth of isolates of $P$. aphanidermatum and $P$. diclinum was similar to that of the effect on the radial mycelial growth, with different values of inhibition, as noted in Table 2.

\section{Effect on zoospore formation}

Data in Fig. 2 and 3 appeared that zoospore formation of $P$. aphanidermatum (JU0010 \& JU0011) and P. diclinum (JU0020 \& JU0021) was high after $24 \mathrm{~h}$ incubation at $25^{\circ} \mathrm{C}$ in the control trial. Distilled water supplemented with quarter and half strengths of filtrates of $P$. oligandrum significantly reduced zoospore production.

\section{Effect on oospore production}

Numbers in Fig. 4 and 5 revealed that oospore production of $P$. aphanidermatum (JU0010 \& JU0011) and P. diclinum (JU0020 \& JU0021) was high after 15 days incubation 

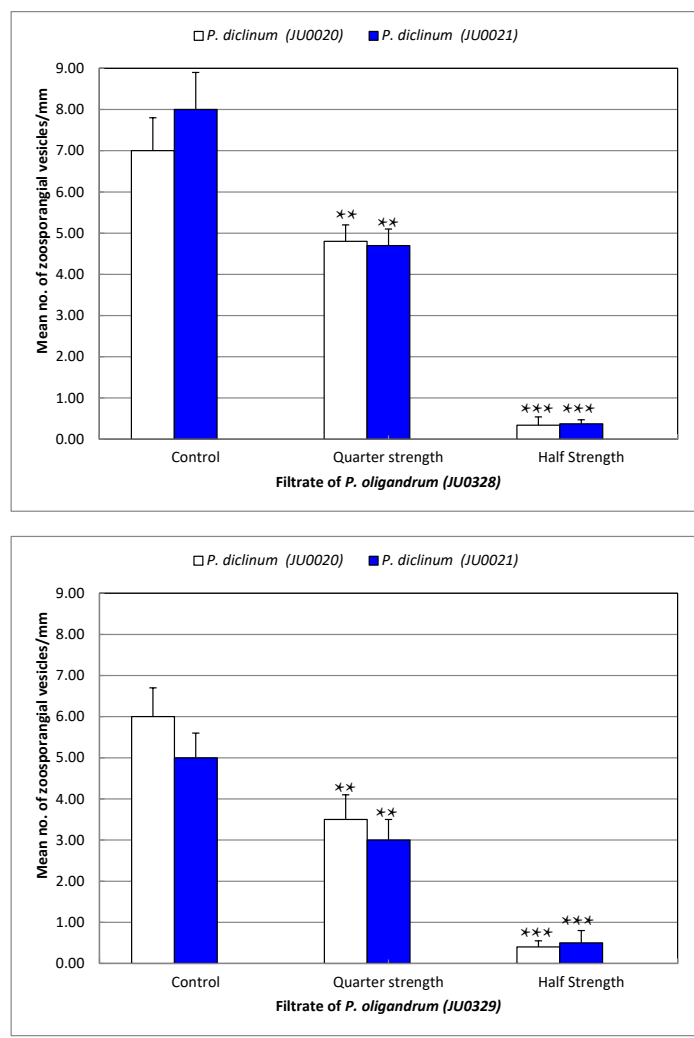

Fig. 2. Effect of cultural filtrate of two isolates of $P$. oligandrum on zoospore production by two isolates of $P$. diclinum after $24 \mathrm{~h}$ at $20^{\circ} \mathrm{C}$ in the dark. Bars above all drawing column, represent the standard error of the average data from three replicates and reflect differences between averages of the samples compared to the control sample. Significant values against control represent: ${ }^{* *}=$ highly significant at $\mathrm{p}<0.01, * * *=$ very significant at $p<0.001$.

at $28^{\circ} \mathrm{C}$ in the control trial. V-8 liquid medium supplemented with quarter and half strengths of filtrates of $P$. oligandrum significantly reduced oospore production.

\section{DISCUSSION}

There are many researches that deal with the role of $P$. oligandrum in increasing productivity of plant crops and biological control of some fungal diseases ${ }^{4,12}$. This fungus is well known as a potential biocontrol agent. Literature review is filled with several researches on the role of this fungus in producing plant like auxin and its use in biocontrol as an organism or even its active secreted ingredient (oligandrin) in this regard ${ }^{4,5,13}$. A previous study postulated that the cell wall degrading enzymes
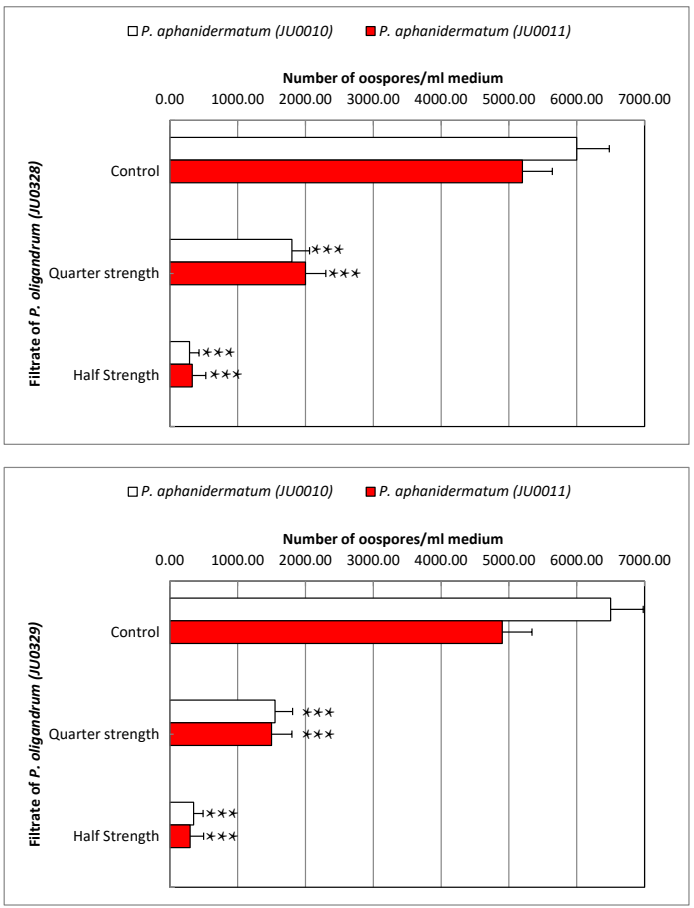

Fig. 3. Effect of cultural filtrate of two isolates of $P$. oligandrum on oospore production by two isolates of P. aphanidermatum after $24 \mathrm{~h}$ at $20^{\circ} \mathrm{C}$ in the dark. Bars above all drawing column, represent the standard error of the average data from three replicates and reflect differences between averages of the samples compared to the control sample. Significant values against control represent: ${ }^{* *}=$ highly significant at $\mathrm{p}<0.01, * * *=$ very significant at $\mathrm{p}<0.001$.

of $\mathrm{N}$-acetyl- $\beta$-D-glucosaminidase (NAGase), endochitinase, protease, $\beta$-glucanase, $\beta$-glucosidase and cellobiohydrolase were noticed in culture filtrates of $P$. oligandrum ${ }^{14}$. Similarly, another study added that the active involvement of substances secreted by $P$. hypogynum Middleton, and $P$. canariense Paul, in providing control against Botrytis cinerea (Pers.) to tomato and bean plants were documented.

For this reason, the idea of this research was focused on the use of cultural filtrates of two isolates of $P$. oligandrum (as a content of inhibitory substances for the growth of the opposite fungi) in curbing mycelial growth, asexual and sexual reproduction of two isolates of the proved (Fig. 1) highly pathogenic species of $P$. aphanidermatum 
Table 2. Effect of the inhibitory activity of different strength of cultural filtrate of two isolates of Pythium oligandrum on mycelial biomass growth of two isolates of each of Pythium aphanidermatum and Pythium diclinum grown on solid V-8 agar medium at $25^{\circ} \mathrm{C}$ in the dark

\begin{tabular}{|c|c|c|c|c|c|c|c|c|}
\hline \multirow[b]{2}{*}{ Treatment } & \multicolumn{2}{|c|}{$\begin{array}{l}\text { P. aphanidermatum } \\
\text { (JU0010) }\end{array}$} & \multicolumn{2}{|c|}{$\begin{array}{l}\text { P. aphanidermatum } \\
\text { (JU0011) }\end{array}$} & \multicolumn{2}{|c|}{$\begin{array}{l}\text { P. diclinum } \\
\text { (JU0020) }\end{array}$} & \multicolumn{2}{|c|}{$\begin{array}{l}\text { P. diclinum } \\
\text { (JU0021) }\end{array}$} \\
\hline & $\begin{array}{c}\text { Dry } \\
\text { weight } \\
(\mathrm{mg} / \\
50 \mathrm{ml})\end{array}$ & $\begin{array}{c}\% \\
\text { inhibition }\end{array}$ & $\begin{array}{c}\text { Dry } \\
\text { weight } \\
(\mathrm{mg} / \\
50 \mathrm{ml})\end{array}$ & $\begin{array}{c}\% \\
\text { inhibition }\end{array}$ & $\begin{array}{c}\text { Dry } \\
\text { weight } \\
\text { (mg/ } \\
50 \mathrm{ml})\end{array}$ & $\begin{array}{c}\% \\
\text { inhibition }\end{array}$ & $\begin{array}{c}\text { Dry } \\
\text { weight } \\
\text { (mg/ } \\
50 \mathrm{ml} \text { ) }\end{array}$ & $\begin{array}{c}\% \\
\text { inhibition }\end{array}$ \\
\hline \multicolumn{9}{|c|}{ P. oligandrum JU0328 } \\
\hline Control (Full strength) ${ }^{1}$ & $97^{4} \pm 3.9$ & - & $86 \pm 4$ & - & $65 \pm 3.5$ & - & $59 \pm 3$ & - \\
\hline Quarter strength ${ }^{2}$ & $46 \pm 2.9$ & $52.6^{* *}$ & $47 \pm 3$ & $45.3^{* *}$ & $33 \pm 3$ & $49.2^{* *}$ & $30 \pm 2$ & $49.2^{* *}$ \\
\hline Half strength ${ }^{3}$ & $11 \pm 1.4$ & $88.7^{* * *}$ & $14 \pm 2$ & $98.8^{* * *}$ & $9 \pm 1$ & $86.2^{* * *}$ & $8 \pm 1$ & $86.4^{* * *}$ \\
\hline \multicolumn{9}{|c|}{ P. oligandrum JU0329 } \\
\hline Control (Full strength) & $110 \pm 5$ & - & $79 \pm 4$ & - & $74 \pm 3$ & - & $69 \pm 3$ & - \\
\hline Quarter strength & $63 \pm 5$ & $42.7^{* *}$ & $39 \pm 3$ & $50.6^{* *}$ & $36 \pm 2$ & $51.3^{* *}$ & $37 \pm 2$ & $46.4^{* *}$ \\
\hline Half strength & $19 \pm 1$ & $82.7^{* * *}$ & $11 \pm 1$ & $86.1^{* * *}$ & $11 \pm 1$ & $85.1^{* * *}$ & $13 \pm 2$ & $81.2^{* * *}$ \\
\hline
\end{tabular}

${ }^{1}$ Control $=$ Full strength $-50 \mathrm{mg} \mathrm{V}-8$ agar medium; ${ }^{2}$ Quarter strength $=12.5 \mathrm{ml}$ filtrate $+37.5 \mathrm{ml} \mathrm{V-8}$ agar medium

${ }^{3}$ Half strength $=25 \mathrm{ml}$ filtrate $+25 \mathrm{ml} \mathrm{V}-8$ agar medium; ${ }^{4}$ Mycelia dry weight growth was determined by weighting mycelial dry weight after 8 days and taking the average. Data are the mean of six reads + standard errors.

${ }^{* *},{ }^{* * *}$ Data are the mean of three replicates and reflect differences between averages of the samples compared to the control sample. Significant values against control represent: ${ }^{* *}=$ highly significant at $\mathrm{p}<0.01,{ }^{* * *}=$ very significant at $\mathrm{p}<0.001$.
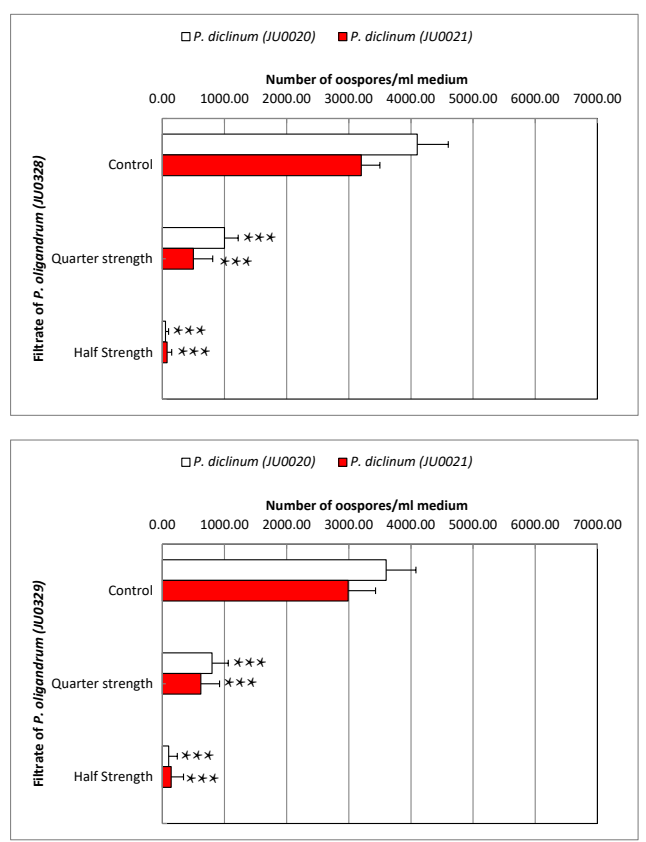

Fig. 4. Effect of cultural filtrate of two isolates of $P$. oligandrum on oospore production by two isolates of $P$. diclinum after $24 \mathrm{~h}$ at $20^{\circ} \mathrm{C}$ in the dark. Bars above all drawing column, represent the standard error of the average data from three replicates and reflect differences between averages of the samples compared to the control sample. Significant values against control represent: $* *=$ highly significant at $p<0.01, * * *=$ very significant at $\mathrm{p}<0.001$.

\section{and $P$. diclinum.}

Data here showed that cultural filtrates of $P$. oligandrum had a strong potential to inhibit mycelial growth of $P$. aphanidermatum and $P$. diclinum (Tables 1,2). Subsequently, observation was confirmed in either radial growth in solid medium or biomass growth in liquid medium and correlates well with previous investigation ${ }^{6}$.

Results in Figures 3 and 4 confirmed

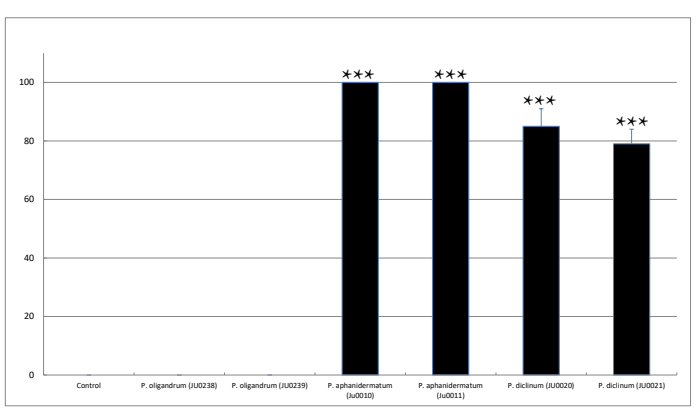

Fig. 5. Pre-emergence damping-off of cucumber germinating seeds grown in clay sand soil infested with tested each of 2 isolates of $P$. oligandrum, $P$. aphanidermatum and $P$. diclinum. Control is all the mixture of the inocula, but without fungal growth. Bars above all drawing column, represent the standard error of the average data from 5 pots $x 20$ seeds $=100$ measurements and reflect differences between averages of the samples compared to the control sample. Significant values against control represent: ${ }^{* *}=$ very significant at $p<0.001$. 
the role of the two isolates of $P$. oligandrum in inhibiting production of zoospores of the two isolates of each $P$. aphanidermatum and $P$. diclinum starting from quadrate to half concentration of $P$. oligandrum filtrates. Results here are consistent with the results of previous experiments, but in the case of the use of $P$. oligandrum itself and not the filtrate of its growth ${ }^{14}$. These results are very suitable for application in aquatic farms where the center of root growth is nutrient solutions, in which swimming zoospores are dangerous factors of infection.

In the same pattern of inhibitory effect, results in Figs 4 \& 5 showed clear and effective inhibitory effect of filtrates of $P$. oligandrum on the production of oospores of the two isolates of each $P$. aphanidermatum and $P$. diclinum. These results are reliable with the results of previous trials, but in the case of the use of $P$. oligandrum itself and not the filtrate of its growth ${ }^{15}$.

Therefore, results of this study confirm that there is no reason to doubt the possibility of using cultural filtrate of $P$. oligandrum to inhibit the formation of all structures of sexual and asexual reproduction in $P$. aphanidermatum and $P$. diclinum, that causing fungal diseases of some crops plants.

Results of this study can be easily applied in hydroponics but need further work on application of cultural filtrate of $P$. oligandrum, and their effect on different types of pathogenic fungi.

\section{ACKNOWLEDGMENTS}

None.

\section{CONFLICT OF INTEREST} conflict of interest.

The author declares that there are no

\section{REFERENCES}

1. Plaats-Niterink, A.J. Van der. Monograph of the genus Pythium. Stud. Mycol., 1981; 21: 1-244.

2. Al-Sheikh, H. and H. M. A. Abdelzaher. "Materials for Pythium flora of Saudi Arabia (I) Occurrence, pathogenicity and physiology of reproduction of Pythium aphanidermatum (Edson) Fitzp. isolated from north and east regions of Saudi Arabia". Res J Microbiol, 2012; 1-19, DOI: 10,3923/jim.
3.

Elnaghy, M. A., H. M. A. Abdelzaher, M. A. Shoulkamy and S. R. "Sayed. Bean (Phaseolus vulgaris L.) dampingoff caused by Pythium ultimum var. ultimum and its possible control by Pythium oligandrum". J Pure Appl Microbiol, 2014; 8(SPL. EDN.): 161-169.

4. Moustafa, S. M. N. and H. M. A. Abdelzaher. "Increasing of Tomato Yield Grown in Hydroponic System Using Pythium oligandrum Isolated from Khoaa, Aljouf, Saudi Arabia". Egypt J. Micro., 2018; 53: 1 - 8.

5. Gaetan L. F. , R. Patrice, B. Emile, B. Nicole and T. Yves." Impact of auxin-compounds produced by the antagonistic fungus Pythium oligandrum or the minor pathogen Pythium group F on plant growth". Plant and Soil, 2003; 257: 459-470.

6. Abdelzaher, H. M. A., M. A. Shoulkamy and M. M. Yasser, "Effect of benomyl and metalaxyl on reproduction of the plant parasite (Pythium deliense) and the mycoparasite ( $P$. oligandrum)". Archives of phytopathol Plant Protect, 2004; 37(4): 307-317.

7. Al-Sheikh, H. and H. M. A. Abdelzaher, " Occurrence, Identification and Pathogenicity of Pythium aphanidermatum, $P$. diclinum, $P$. dissotocum and Pythium "group $\mathrm{P}$ " Isolated from Dawmat Al Jandal Lake, Saudi Arabia". Res J Environment Sci, 2012; 6(6): 196-209.

8. Allen, T.W., A. Martinez, and L.L. Burpee. 2004. Pythium blight of turfgrass. The Plant Health Instructor. DOI:10.1094/PHI-I-2004-0929-01. Updated by A. Martinez, 2016.

9. Martinez-Espinoza, A.D. 2016. Evaluation of fungicide efficacy for control of dollar spot on Seashore paspalum in Georgia, 2013. Plant Disease Management Reports PDMR 10: T022.

10. Pal, K. K. and B. McSpadden Gardener, 2006. Biological Control of Plant Pathogens The Plant Health Instructor. DOI: 10.1094/PHI-A-2006-1117-02.

11. Koch, R., "Die Aetiologie der Tuberculose" [The etiology of tuberculosis]. Berliner Klinische Wochenschrift (Berlin Clinical Weekly) 1882; 19: 221-30.

12. Abdelzaher, H. M. A., M. A. Elnaghy and E. M. FadlAllah. "Isolation of Pythium oligandrum from Egyptian soil and its mycoparasitic effect on Pythium ultimum var. ultimum the damping-off organism of wheat". Mycopathologia, 1997; 139(2): 97-106.

13. Picard, K., M. Ponchet, J. P. Blein, P. Rey, Y. Tirilly and N. Benhamou. Oligandrin. A proteinaceous molecule produced by the mycoparasite Pythium oligandrum induces resis-tance to Phytophthora parasitica infection in tomato plants. Plant Physiol 2000; 124: 379-396.

14. Bala, K., D. R. David, B. Paul and Y. Elad. "Pythium elicitors in biological control of Botrytis cinerea" Multitrophic Interactions in Soil, IOBC/wprs Bulletin 2009; 42: 11-14.

15. Madsen A. M. and E. Neergaard. "Interactions between the mycoparasite Pythium oligandrum and sclerotia of the plant pathogen Sclerotinia sclerotiorum". Euro J Plant Pathol, 1999; 105: 761-768. 